\title{
Same-admission laparoscopic cholecystectomy in acute cholecystitis: the importance of 72 hours and oxidative stress markers
}

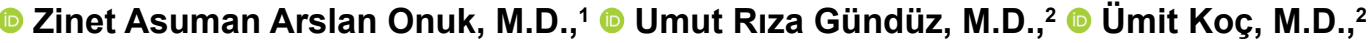 \\ (1) Esra Kızılateş, M.D., ${ }^{1}$ IIsmail Gömceli, M.D., ${ }^{2} \odot$ S. Halide Akbaş, M.D., ${ }^{3}$ \\ (1) Nurullah Bülbüller, M.D. ${ }^{4}$
}

1'Department of Anesthesiology and Reanimation, University of Health Science, Antalya Training and Research Hospital, Antalya-Turkey ${ }^{2}$ Department of General Surgery, University of Health Science, Antalya Training and Research Hospital, Antalya-Turkey

${ }^{3}$ Department of Medical Biochemistry, Akdeniz University Faculty of Medicine, Antalya-Turkey

${ }^{4}$ Department of General Surgery, Akdeniz University Faculty of Medicine, Antalya-Turkey

\begin{abstract}
BACKGROUND: This prospective randomized study aims to compare outcomes between immediate laparoscopic cholecystectomy (LC) and same admission delayed LC in patients with acute cholecystitis and also to investigate the relation between oxidative stress markers and complication rates in the patients with AC.

METHODS: This study included 64 patients with AC who were randomly divided into two groups. Patients in Group I ( $n=32$ ) were immediately administered LC, while in Group $2(n=32)$ patients underwent transient LC following medical treatment. All patients were operated on their first hospitalization.

RESULTS: No statistically significant differences were observed between the groups for the comparison of complications, conversion rates, or operation durations $(p>0.05)$. The length of postoperative hospital stay was found to be significantly shorter in group I compared to group 2 ( 1.75 vs 2.93 days; $p=0.024)$. Only the total antioxidant status result was significantly higher in group I $(p=0.017)$, but the finding was not correlated with complications.
\end{abstract}

CONCLUSION: LC for AC was performed during the first admission was found to be safe, even beyond 72 hours following symptom onset. Pre-operative oxidative stress markers did not correlate with the complication rates.

Keywords: 72 hours; acute cholecystitis; oxidative stress; same admission.

\section{INTRODUCTION}

Gallstone disease is one of the most common problems of the digestive tract. Autopsy reports have shown a prevalence of gallstones between $11 \%$ and 36\%. ${ }^{[1]}$ Many conditions are associated with an increased risk of developing gallstones, such as obesity, pregnancy, dietary factors, Crohn's disease, terminal ileum resection, gastric surgery, hereditary spherocytosis, sickle cell disease, and thalassemia. ${ }^{[2]}$ Most of the patients remain asymptomatic throughout life, but some patients progress to a symptomatic stage. Symptomatic gallstone disease may present as acute or chronic cholecystitis, choledocholithiasis with or without cholangitis, gallstone pancreatitis, cholecystocholedochal fistula, cholecystoduodenal fistula leading to gallstone ileus, and gallbladder carcinoma. ${ }^{[3]}$

Acute cholecystitis (AC) is a well-known complication of gallstone disease, and $A C$ is a potentially life-threatening condi-

Cite this article as: Arslan Onuk ZA, Gündüz UR, Koç Ü, Kızılateş E, Gömceli İ, Akbaş SH, et al. Same-admission laparoscopic cholecystectomy in acute cholecystitis: the importance of 72 hours and oxidative stress markers. Ulus Travma Acil Cerrahi Derg 2019;25:440-446.

Address for correspondence: Umut Rıza Gündüz, M.D.

Sağıık Bilimleri Üniversitesi, Antalya Eğitim ve Araştırma Hastanesi, Genel Cerrahi Kliniği, Antalya, Turkey

Tel: +90 242 - 2494400 E-mail: utgl@yahoo.com

Ulus Travma Acil Cerrahi Derg 2019;25(5):440-446 DOI: 10.14744/tjtes.2019.17807 Submitted: 19.10.2018 Accepted: 09.01.2019 Online: 22.08.2019

Copyright 2019 Turkish Association of Trauma and Emergency Surgery 
tion due to its related complications. Laparoscopic cholecystectomy (LC) was once considered a relative contraindication in the presence of $A C$ because of increased morbidity and conversion rates. ${ }^{[4,5]}$ Today, there are studies that have shown that LC is the most common treatment for AC, which is a result of improvements in the laparoscopic skills and experiences of medical teams. ${ }^{[6]}$ However, there has been a lack of agreement regarding the timing of the operation for the treatment of AC. Oxidative stress responses, which are characterized by a balance between pro-oxidants and antioxidants, are an integral part of the response to surgical stress and the activation of inflammatory cells. ${ }^{[7,8]}$ This prospective randomized study aimed to compare the clinical and surgical results of the LC, which was applied early (within 72 hours as of the symptoms' onset) and delayed (72 hours later as of the symptoms onset), and to discuss the 72-hour rule's importance in light of the literature. In this study, the secondary aim was to compare the oxidative stress response between early and late cholecystectomy patient groups, and then, evaluate the relationship between oxidative stress markers and complications in patients with AC.

\section{MATERIALS AND METHODS}

\section{Study Design and Patients}

This prospective, single-center study was conducted at the University of Health Science, Antalya Training and Research Hospital, in Turkey. Parallel patient groups were created, and the randomization of the groups was balanced $(I: I)$. This study was approved by the institutional ethics committee at the University of Health Science, Antalya Training and Re- search Hospital, in Turkey (\#2012/029). The trial was conducted in accordance with the most recent version of the Declaration of Helsinki, and the results were presented according to the CONSORT guidelines. This study was registered with researchregistry.com (UIN: 2383). The diagnosis of $A C$ was established on the basis of local (that is, Murphy's sign, right upper quadrant pain) and systemic (that is, fever, elevated white blood cell, and/or C-reactive protein) signs of inflammation and confirmed by ultrasound according to Tokyo guidelines (TGI3). ${ }^{[9]}$ The abdominal ultrasound was performed by trained radiologists, and intraluminal pathologies and thickening of the gallbladder wall were recorded. The patient exclusion criteria were sepsis, immunosuppression, perforated cholecystitis, choledocholithiasis, cholangitis, acute pancreatitis, previous upper abdominal surgery, pregnancy, and patients who declined to participate in this study. Every patient provided a written informed consent before enrollment.

Between January 2013 and December 2014, 293 patients were admitted for AC. After applying exclusion criteria (159 patients admitted 72 hours after the onset of symptoms, four patients with sepsis, two patients under immunosuppression, three patients with perforated cholecystitis, 14 patients with choledocholithiasis, 27 patients with acute pancreatitis, seven patients with previous upper abdominal surgery, one patient was pregnant, and 12 patients refused to participate in the study), 64 patients were included in this study (Fig. I). Randomization was done by an assistant who was not involved in the enrolment or this study. Study assistant assigned randomly to early (group I) or delayed (group 2) LC, by picking out

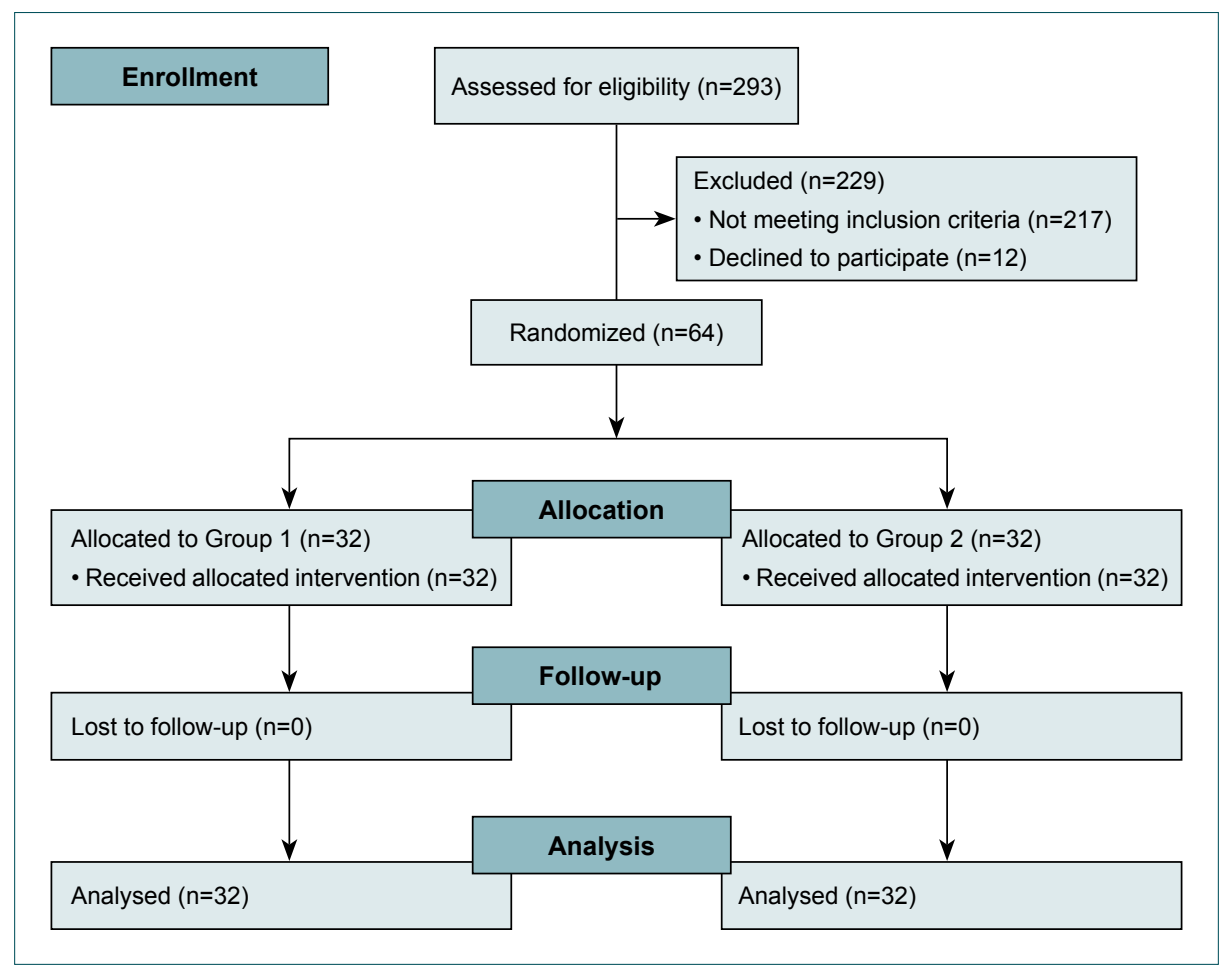

Figure 1. CONSORT flow diagram. 
of an opaque box and opening a sealed opaque randomization envelope. The details of the allocated groups ('I' or '2') were given on cards contained in sealed opaque envelopes. All sealed opaque envelopes were previously prepared with a I: I ratio, well-shuffled and put into a box by the dedicated study assistant. No blinding was performed. The early operation group was operated on within 72 hours of the onset of symptoms (32 patients), whereas the late operation group was operated on during the same hospital admission following initial treatment (4-6 days) (32 patients). Operations were performed by staff surgeons of our clinic who were experienced in laparoscopic and open surgery. All patients were treated with intravenous fluids, antibiotics, and analgesics.

\section{Interventions}

In both groups, intravenous antibiotics (I g of Ceftriaxone $2 \times \mathrm{l}$ and $500 \mathrm{mg}$ of Metronidazole $4 \mathrm{xl}$ ) were administered upon diagnosis of AC, according to TGI3.9 Blood samples for the analysis of oxidative stress markers were collected before the operation. Blood specimens were centrifuged for $10 \mathrm{~min}$ at $2,000 \mathrm{~g}$, the resulting serum was transferred to Eppendorf tubes, and the samples were stored at $-80^{\circ} \mathrm{C}$. The specimens were used to measure advanced oxidation protein products (AOPP), sulfhydryl groups (SG), total antioxidant status (TAS), and total oxidant status (TOS).

All patients underwent general anesthesia. The anesthetic technique was standardized for all patients and consisted of balanced anesthesia. All patients were premedicated with diazepam $5 \mathrm{mg}$ the night before surgery and with midazolam $0.03 \mathrm{mg} / \mathrm{kg}$ intravenously (IV) 10 minutes preoperatively. Anesthesia was induced with thiopental $(5 \mathrm{mg} / \mathrm{kg})$ and fentanyl $(4 \mu \mathrm{g} / \mathrm{kg})$. Vecuronium was used as a muscle relaxant $(0.1-0.15 \mathrm{mg} / \mathrm{kg})$. After tracheal intubation, anesthesia was maintained with a $50 \%$ air/oxygen mixture with desflurane at a concentration of $4 \%$ to $5 \%$. Additional fentanyl and vecuronium were administered whenever necessary.

The LC procedure used a standard four-port technique. A Hasson-type trocar was inserted at the periumbilical region for the laparoscope. Carbon dioxide was used for peritoneal insufflation, and abdominal pressure was maintained between $10 \mathrm{mmHg}$ and $12 \mathrm{mmHg}$. Operator access ports of $10 \mathrm{~mm}$ and $5 \mathrm{~mm}$ in diameter were inserted into the epigastrium and the right hypochondrium, respectively. The fundus of the gallbladder was grasped with the forceps inserted via a 5-mm port placed at the right upper quadrant. If it were difficult to grasp the gallbladder due to inflammation and the thickness of the wall, gallbladder decompression would be performed using a Veress needle. If severe inflammation and adhesion were present, blunt dissection with a suction device was useful to provide a clear field, and the tissues were dissected safely. The cystic duct and cystic artery were dissected at Calot's triangle. The critical view of safety established in each case, so intraoperative cholangiography was not performed. Total cholecystectomy was performed for all patients. A drain was routinely inserted to the subhepatic area to assess intraperitoneal bleeding and bile leakage postoperatively. A pathological diagnosis was routinely performed to confirm AC.

Demographics, clinical data, laboratory tests, ultrasonography (gall bladder wall thickness: $3 \mathrm{~mm} />3 \mathrm{~mm}$ ), and operative and postoperative variables (such as operation time, number of postoperative hospitalization days, intraoperative and postoperative adverse events, and rate of conversion to open cholecystectomy) were recorded for all of the patients. The primary evaluation criterion of this study was overall morbidity, which was defined as any adverse event that occurred from the time of diagnosis until the $30^{\text {th }}$ postoperative day. The secondary outcome of this study was a comparison of the oxidative stress parameters (AOPP, SG, TAS, TOS, and OSI) between early and late cholecystectomy patient groups and whether there was an association with complications. According to our clinical experience, there is no clinical significance of the 'early' concept in acute cholecystitis patients. In addition, different time frames for early cholecystectomy are described in the current literature. This study is based on this hypothesis.

\section{Oxidative Stress Markers}

Measurement of advanced oxidation protein products (AOPP) Spectrophotometric measurement of AOPP levels was performed with a V-Twin analyzer by Witko's method. ${ }^{[10]}$ The results are expressed in $\mu \mathrm{mol} / \mathrm{L}$.

\section{Measurement of Sulfhydryl Groups (SG)}

Plasma sulfhydryl groups originated predominantly from plasma proteins, and they participate in the defense against oxidative stress. Measurement of total free sulfhydryl groups (serum-SH levels) was assayed according to the method of Ellman, as modified by Hu et al. ${ }^{[1,12]}$ The SG amount was expressed in $\mathrm{mol} / \mathrm{L}$.

\section{Measurement of Total Antioxidant Status of Serum (TAS)}

The total antioxidant status of the serum was determined using a novel spectrophotometric measurement method developed by Erel. ${ }^{[13]}$ The results are expressed in $\mu \mathrm{mol}$ of Trolox equivalents/L.

\section{Measurement of Total Oxidant Status (TOS)}

TOS of serum was determined using a novel spectrophotometric measurement method, as previously described by Erel. [14] The results are expressed in terms of the $\mu \mathrm{mol}$ hydrogen peroxide equivalent per liter ( $\mu \mathrm{mol}$ of $\mathrm{H}_{2} \mathrm{O}_{2}$ Equiv/L).

\section{Oxidative Stress Index (OSI)}

The ratio of TOS to TAS was accepted as the oxidative stress index (OSI). The OSI value was calculated according to the 
following formula: OSI (arbitrary unit) $=[($ TOS, $\mu \mathrm{mol}$ of $\mathrm{H}$ equivalent/L) / (TAS, $\mu \mathrm{mol}$ of Trolox equivalent/L) $\times 100]$.

\section{Statistical Analysis}

The study data were summarized with descriptive statistics (mean, SD, frequency, and percentage). The comparisons between study groups were performed using the Mann-Whitney $U$ test for continuous variables and the Pearson chi-square test for categorical variables. The statistical level of significance was set to $p<0.05$. Data were analyzed with Statistical Package for Social Sciences (SPSS 2I.0, Inc., Chicago, IL). We performed this study with 32 experimental subjects and 32 control subjects. According to post hoc power analysis, our data indicate that the true probability of exposure among group 2 is 0.281 . The true probability of exposure among group $I$ is 0.125 . We can reject the null hypothesis that the exposure rates for group 2 and group I are equal with a probability (power) equal to 0.34 . The probability of a type I error associated with the test of this null hypothesis is 0.05 . We used an uncorrected chi-squared statistic to evaluate this null hypothesis (software: PS Power and Sample Size Calculations, Version 3.0).

\section{RESULTS}

The median age of the patients was 53.6 (27-83) years. There were no differences between the study groups for age or sex distribution ( $p>0.05)$. Hypertension was the most common comorbidity in all patients. 17 patients $(26.5 \%)$ had hypertension, 7 (10.9\%) patients had diabetes, 4 patients (6.25\%) had thyroid disease (Hashimoto's Disease), and one patient (I.5\%) had pulmonary disease (asthma) (Table I). Comorbidities were also similar between groups ( $p>0.05$ ). In laboratory findings, white blood cell, ALT, ALP, and direct bilirubin results were not different between groups $(p>0.05)$, but AST, GGT, and total bilirubin results were significantly higher in the group one patient $(p=0.002, p=0.001, p=0.001$, respectively) (Table 2 ). In terms of oxidative stress markers, only TAS result were significantly higher in the group I patients $(p=0.005)$; other oxidative stress results (AOPP, SG, TOS, and OSI) were not different between groups ( $p>0.05)$ (Table 3). There were similar ultrasonography characteristics in both groups; calculi in the gallbladder were detected in all of the patients, and the thickness of the gallbladder wall was increased in $10(31.3 \%)$ and $8(25.0 \%)$ patients in group I and group 2, respectively ( $>>0.05$ ). Length of operation seemed to be shorter in group 2, but there were no significant differences in either group (mean $64.6 \mathrm{~min}$ in group I vs $50.7 \mathrm{~min}$ in group 2; $>>0.05$ ). Only one patient (in group 2) converted to open surgery, due to tissue adhesions and inflammation. Overall morbidity was similar in both groups. Postoperative complications were observed in four patients in group I (12.5\%) and nine patients in group $2(28.1 \%)(p>0.05)$. All complications (wound infection on trocar site, perihepatic fluid, a hematoma on trocar site, and
Table I. Clinical and demographic features of the patients

\begin{tabular}{lcc}
\hline & $\begin{array}{c}\text { Group I } \\
(\mathbf{n}=32)\end{array}$ & $\begin{array}{c}\text { Group 2 } \\
(\mathbf{n}=\mathbf{3 2})\end{array}$ \\
\hline Age (years), mean \pm SD & $54.04 \pm 15.83$ & $53.53 \pm 11.19$ \\
Sex ratio (female/male) & $19 / 13$ & $20 / 12$ \\
Hypertension & 8 & 9 \\
Diabetes mellitus & 3 & 4 \\
Thyroid disease & 2 & 2 \\
Pulmonary disease & 1 & - \\
ASA I & 18 & 17 \\
ASA II & 14 & 15 \\
\hline
\end{tabular}

ASA: American Society of Anesthesiologists; SD: Standard deviation.

Table 2. Laboratory results

\begin{tabular}{lcccc}
\hline & Group I $(\mathbf{n}=32)$ & & Group $2(\mathbf{n}=32)$ & p \\
\cline { 2 - 2 } & Mean \pm SD & & Mean \pm SD & \\
\hline WBC & $8.89 \pm 3.83$ & & $8.09 \pm 2.55$ & 0.573 \\
AST & $47.09 \pm 48.53$ & & $20.97 \pm 7.50$ & $0.002^{\mathrm{a}}$ \\
ALT & $62.88 \pm 80.71$ & & $22.34 \pm 12.55$ & 0.055 \\
ALP & $\mid 12.25 \pm 143.89$ & & $68.31 \pm 21.35$ & 0.129 \\
GGT & $\mid 26.91 \pm 202.61$ & & $38.96 \pm 81.49$ & $0.00 I^{\mathrm{a}}$ \\
TB & $0.98 \pm 0.57$ & & $0.50 \pm 0.22$ & $0.001^{\mathrm{a}}$ \\
DB & $0.34 \pm 0.31$ & & $0.21 \pm 0.07$ & 0.582 \\
\hline
\end{tabular}

aStatistically significant $(p<0.05)$. WBC: White blood cell; AST: Aspartate aminotransferase; ALT: Alanine aminotransferase; ALP: Alkaline phosphatase; GGT: Gamma-glutamyltransferase; TB: Total bilirubin; DB: Direct bilirubin; SD: Standard deviation.

Table 3. Oxidative stress markers results

\begin{tabular}{lccc}
\hline & Mean \pm SD & Mean \pm SD & p \\
\hline AOPP & $12.66 \pm 5.62$ & $15.16 \pm 7.27$ & 0.270 \\
SG & $389.89 \pm 111.58$ & $441.07 \pm 247.71$ & 0.711 \\
TAS & $1.61 \pm 0.24$ & $1.41 \pm 0.25$ & $0.017^{\mathrm{a}}$ \\
TOS & $8.75 \pm 5.39$ & $11.26 \pm 8.69$ & 0.635 \\
OSI & $0.55 \pm 0.33$ & $0.78 \pm 0.56$ & 0.203 \\
\hline
\end{tabular}

aStatistically significant $(\mathrm{p}<0.05)$. AOPP: Advanced oxidation protein products; SG: Sulfhydryl groups; TAS: Total antioxidant status; TOS: Total oxidant status; SD: Standard deviation.

postoperative ileus) were grade I or grade II complications, according to the Clavien-Dindo classification, ${ }^{[15]}$ so there was no need for any surgical or endoscopic interventions for complications. The mean postoperative length of stay was significantly shorter in group I ( 1.75 vs 2.93 days; $p=0.00 \mathrm{I})$ (Table 4). 
Table 4. Surgical data and complications

\begin{tabular}{|c|c|c|c|}
\hline & Group I $(n=32)$ & Group $2(n=32)$ & $\mathbf{p}$ \\
\hline Increased gallbladder wall thickness (number of patients) & 10 & 8 & 0.578 \\
\hline Operative time (min.), mean $\pm S D$ & $64.69 \pm 34.50$ & $50.78 \pm 17.92$ & 0.178 \\
\hline Post-operative hospital stay in days, mean $\pm S D$ & $1.75 \pm 1.41$ & $2.93 \pm 1.83$ & $0.024^{\mathrm{a}}$ \\
\hline Complications (number of patients) & Total $=4$ & Total $=9$ & 0.120 \\
\hline Wound infection ${ }^{\mathrm{b}}$ & 2 & 3 & \\
\hline Hematoma $^{c}$ & I & 2 & \\
\hline Perihepatic fluid & I & 3 & \\
\hline Postoperative ileus & 0 & I & \\
\hline
\end{tabular}

a'Statistically significant $(\mathrm{p}<0.05)$; ${ }^{b}$ Superficial infection on trocar site; In abdominal wall. SD: Standard deviation.

\section{DISCUSSION}

When we evaluated the results of the $A C$ in the emergency department of our hospital, we observed that the vast majority of the patients were operated on after a long length of time following medical treatment (6-8 week). A small number of patients undergo early surgical treatment, which we think is caused by the high number of emergency patients who are referred to our hospital. Separate admissions for medical and surgical treatments make the cost of treatment high and result in loss of days off work. Early surgical treatment in acute cholecystitis is the first option, but the treatment of late-onset patients is controversial.

The present study, which is a prospective randomized controlled study, focused on surgical treatments of patients with AC during the first admissions even if more than 72 hours have elapsed since the onset of symptoms, and the predictive value of oxidative stress markers in terms of the complications of AC. To our knowledge, the present study is the first randomized controlled trial, including LC performed for $A C$ patients in the same admission. An increased number of studies have pointed toward the importance of the timing of the operation for the treatment of AC. The rule of "72 hours after the symptoms" has been previously examined in retrospective studies, ${ }^{[16-18]}$ and similar rates of postoperative complications and conversion to open surgery have been observed for both early and delayed patient groups beyond 72 hours of symptoms. The time limit for early LC is defined in some studies as the first 72 hours following symptom onset, ${ }^{[16-18]}$ and in other studies, it is describe as the first I to 10 days. ${ }^{[19-23]}$ Regardless of the timing of the concept of "early", all of the above-mentioned studies showed that early LC was associated with a reduction in the length of stay, workdays lost, and costs without an increase in conversion or perioperative complications. ${ }^{[16-23]}$ Another important issue in the delayed group ( $1-8$ weeks) is gallstone-related morbidity during the waiting period for a cholecystectomy. [16-18,21,23] The most common morbidity is the non-resolution or recurrence of cholecystitis, which occurred in 18.3-29.5\% of patients. ${ }^{[23,24]}$ According to a Cochrane review, the patients who experienced non-resolution of symptoms under initial conservative treatment or recurrence of symptoms during the waiting period necessitating an emergency LC with a high conversion rate of $45 \% .{ }^{[23]}$ In the present study, we found no significant differences in postoperative complication, operation time or conversion rates whether LC had been performed at as soon as possible with AC or 72 hours after the symptoms had settled. When the same review is compared with our study, between early and late group results are similar in terms of complication, operation time, or conversion rates. ${ }^{[23]}$ Moreover, the early LC strategy had the advantage of decreasing the overall hospital stay and the total duration of antibiotic therapy. Only one patient in the delayed LC group has had a conversion to open surgery. Maybe partial cholecystectomy could be performed instead of open surgery, but we did not perform partial cholecystectomy to prevent the equality of groups. ${ }^{[25]}$ This low conversion rate is compatible with rates described in the literature in some retrospective or prospective studies. ${ }^{[16,17,24]}$ In contrast, other retrospective studies that had relatively high patient volumes showed high conversion rates (19.7-25.2\%), especially in the early LC patient group. ${ }^{[18,21]}$ This could be explained by an experienced surgery team or centers. ${ }^{[24]}$ There was no statistically significant difference in terms of operation time in both groups. These findings are similar to many studies in the literature, but in these studies, it was seen that the patients in the late group operated between 8 days and 12 weeks. ${ }^{[1,18,21-24]}$ In one retrospective study, it is shorter in the early cholecystectomy group. ${ }^{[16]}$ A meta-analysis study involving fifteen randomized controlled trials reported that the operative time in the early cholecystectomy group (seven days following symptom onset) was significantly longer. ${ }^{[22]}$

In an inflammatory condition, such as AC, inflammatory cells (for example, granulocytes and mastocytes) are recruited to the site of inflammation, and they subsequently cause an increase in the uptake of oxygen and, thus, free radicals. Free radicals cause lipid peroxidation in cellular membranes, which results in increased permeability, interstitial edema, and more 
inflammatory cell infiltration and activation. Activated inflammatory cells produce potent mediators, including metabolites of arachidonic acid, cytokines, and chemokines, which leads to more free radical production; this cascade may eventually cause cell death..$^{[7,8]}$ Nowadays, a variety of oxidative stress markers have been measured to reflect oxidative stress. The secondary aim of this study was to evaluate the association between complications of $A C$ and oxidative stress markers, and for those measurements, we used AOPP, SG, TAS, TOS, and OSI. Only the TAS result was significantly higher in the early LC group, but we did not find any correlations between TAS levels and complications $(p=0.936)$. The reason for these results may be the small number of patients in the study groups and similar complication rates between groups. On the other hand, this may be due to the collection of blood samples before surgery in both groups of patients. According to the results of this study, we suggest applying immediate cholecystectomy at first admission, regardless of when the symptoms start. There are some limitations to our study. The number of patients in this study was small because of the limited availability of the oxidative stress kit, and many patients with $A C$ were not included in this study due to strict exclusion criteria. As a result of the study plan, the shortterm results were examined, and therefore, we do not have long-term results of this study.

In conclusion, early LC for AC, even beyond 72 hours of symptom onset, is safe and is associated with similar overall morbidity and shorter total hospital stay compared with delayed LC. Performing LC as soon as possible without any time limit between the onset of symptoms and the operation may be recommended in the first admission.

\section{Conflict of interest: None declared.}

\section{REFERENCES}

1. Brett M, Barker DJ. The world distribution of gallstones. Int J Epidemiol 1976;5:335-41. [CrossRef]

2. Al-Jiffry BO, Shaffer EA, Saccone GT, Downey P, Kow L, Toouli J. Changes in gallbladder motility and gallstone formation following laparoscopic gastric banding for morbid obestity. Can J Gastroenterol 2003;17:169-74. [CrossRef]

3. Attili AF, De Santis A, Capri R, Repice AM, Maselli S. The natural history of gallstones: the GREPCO experience. The GREPCO Group. Hepatology 1995;21:655-60. [CrossRef]

4. Cameron JL, Gadacz TR. Laparoscopic cholecystectomy. Ann Surg 1991;213:1-2. [CrossRef]

5. Phillips EH, Carroll BJ, Fallas MJ. Laparoscopically guided cholecystectomy: a detailed report of the first 453 cases performed by one surgical team. Am Surg 1993;59:235-42.

6. Menahem B, Mulliri A, Fohlen A, Guittet L, Alves A, Lubrano J. Delayed laparoscopic cholecystectomy increases the total hospital stay compared to an early laparoscopic cholecystectomy after acute cholecystitis: an updated meta-analysis of randomized controlled trials. HPB (Oxford) 2015;17:857-62. [CrossRef]
7. Misthos P, Katsaragakis S, Theodorou D, Milingos N, Skottis I. The degree of oxidative stress is associated with major adverse effects after lung resection: a prospective study. Eur J Cardiothorac Surg 2006;29:591-5.

8. Shimanuki T, Nakamura RM, diZerega GS. A kinetic analysis of peritoneal fluid cytology and arachidonic acid metabolism after abrasion and reabrasion of rabbit peritoneum. J Surg Res 1986;41:245-51. [CrossRef]

9. Takada T, Strasberg SM, Solomkin JS, Pitt HA, Gomi H, Yoshida M, et al. TG13: Updated Tokyo Guidelines for the management of acute cholangitis and cholecystitis. J Hepatobiliary Pancreat Sci 2013;20:1-7.

10. Witko-Sarsat V, Friedlander M, Capeillère-Blandin C, Nguyen-Khoa T, Nguyen AT, Zingraff J, et al. Advanced oxidation protein products as a novel marker of oxidative stress in uremia. Kidney Int 1996;49:1304-13.

11. Ellman G, Lysko H. A precise method for the determination of whole blood and plasma sulfhydryl groups. Anal Biochem 1979;93:98-102.

12. Hu ML, Louie S, Cross CE, Motchnik P, Halliwell B. Antioxidant protection against hypochlorous acid in human plasma. J Lab Clin Med 1993;121:257-62.

13. Erel O. A novel automated method to measure total antioxidant response against potent free radical reactions. Clin Biochem 2004;37:112-9.

14. Erel O. A new automated colorimetric method for measuring total oxidant status. Clin Biochem 2005;38:1103-11. [CrossRef]

15. Dindo D, Demartines N, Clavien PA. Classification of surgical complications: a new proposal with evaluation in a cohort of 6336 patients and results of a survey. Ann Surg 2004;240:205-13. [CrossRef]

16. Zhu B, Zhang Z, Wang Y, Gong K, Lu Y, Zhang N. Comparison of laparoscopic cholecystectomy for acute cholecystitis within and beyond $72 \mathrm{~h}$ of symptom onset during emergency admissions. World J Surg 2012;36:2654-8. [CrossRef]

17. Gomes RM, Mehta NT, Varik V, Doctor NH. No 72-hour pathological boundary for safe early laparoscopic cholecystectomy in acute cholecystitis: a clinicopathological study. Ann Gastroenterol 2013;26:340-5.

18. Degrate L, Ciravegna AL, Luperto M, Guaglio M, Garancini M, Maternini M, et al. Acute cholecystitis: the golden 72 -h period is not a strict limit to perform early cholecystectomy. Results from 316 consecutive patients. Langenbecks Arch Surg 2013;398:1129-36. [CrossRef]

19. Ansaloni L, Pisano M, Coccolini F, Peitzmann AB, Fingerhut A, Catena F, et al. 2016 WSES guidelines on acute calculous cholecystitis. World J Emerg Surg 2016;11:25. [CrossRef]

20. Bouassida M, Hamzaoui L, Mroua B, Chtourou MF, Zribi S, Mighri $\mathrm{MM}$, et al. Should acute cholecystitis be operated in the $24 \mathrm{~h}$ following symptom onset? A retrospective cohort study. Int J Surg 2016;25:88-90.

21. Sánchez-Carrasco M, Rodríguez-Sanjuán JC, Martín-Acebes F, LlorcaDíaz FJ, Gómez-Fleitas M, Zambrano Muñoz R, et al. Evaluation of Early Cholecystectomy versus Delayed Cholecystectomy in the Treatment of Acute Cholecystitis. HPB Surg 2016;2016:4614096. [CrossRef]

22. Lyu Y, Cheng Y, Wang B, Zhao S, Chen L. Early versus delayed laparoscopic cholecystectomy for acute cholecystitis: an up-to-date meta-analysis of randomized controlled trials. Surg Endosc 2018;32:4728-41.

23. Gurusamy KS, Davidson C, Gluud C, Davidson BR. Early versus delayed laparoscopic cholecystectomy for people with acute cholecystitis. Cochrane Database Syst Rev 2013;6:CD005440. [CrossRef]

24. Roulin D, Saadi A, Di Mare L, Demartines N, Halkic N. Early Versus Delayed Cholecystectomy for Acute Cholecystitis, Are the 72 hours Still the Rule?: A Randomized Trial. Ann Surg 2016;264:717-22. [CrossRef]

25. Sormaz İC, Soytaş Y, Gök AFK, Özgür İ, Avtan L. Fundus-first technique and partial cholecystectomy for difficult laparoscopic cholecystectomies. Ulus Travma Acil Cerrahi Derg 2018;24:66-70. 


\section{ORİIINAL ÇALIŞMA - ÖZET}

\section{Akut kolesistitde laparoskopik kolesistektominin zamanlaması: İlk 72 saat ve oksidatif stres belirteçlerinin önemi \\ Dr. Zinet Asuman Arslan Onuk, ${ }^{1}$ Dr. Umut Rıza Gündüz, ${ }^{2}$ Dr. Ümit Koç, ${ }^{2}$ Dr. Esra Kızılateş, ${ }^{1}$ Dr. İsmail Gömceli, ${ }^{2}$ Dr. S. Halide Akbaş, ${ }^{3}$ Dr. Nurullah Bülbüller ${ }^{4}$}

${ }^{1}$ Sağlık Bilimleri Üniversitesi, Antalya Eğitim ve Araştırma Hastanesi, Anestezi ve Reanimasyon Kliniği, Antalya ${ }^{2}$ Sağlık Bilimleri Üniversitesi, Antalya Eğitim ve Araştırma Hastanesi, Genel Cerrahi Kliniği, Antalya

${ }^{3}$ Akdeniz Üniversitesi Tıp Fakültesi, Tıbbi Biyokimya Anabilim Dalı, Antalya

${ }^{4}$ Akdeniz Üniversitesi Tıp Fakültesi, Genel Cerrahi Anabilim Dalı, Antalya

AMAÇ: Bu ileriye yönelik randomize çalışmanın amacı; akut kolesistitli (AK) hastalarda, hemen yapılan laparoskopik kolesistektomi (LK) ameliyatı ile medikal tedavi altında geçiktirilerek yapılan LK ameliyatının sonuçlarını kıyaslamaktır. Ayrıca ameliyat öncesi serumda bakılan oksidatif stres belirteçleri ile komplikasyon oranları arasındaki ilgiyi ortaya koymaktır.

GEREÇ VE YÖNTEM: Bu çalışmaya AK tanılı 64 hasta dahil edildi ve hastalar rastgele iki gruba ayırıldı. Grup I'deki $(n=32)$ hastalara hemen LK uygulanırken, grup 2'deki $(n=32)$ hastalara medikal tedaviyi takiben geciktirilmiş LK uygulandı. Tüm hastalar ilk yatışlarında ameliyat edildi.

BULGULAR: Her iki grup arasında, komplikasyon, konversiyon oranları ve operasyon süreleri açısından istatistiksel anlamlı fark yoktur ( $p>0.05$ ). Ameliyat sonrası hastanede yatış süresi grup I'de istatistiksel olarak anlamlı oranda daha kısa olarak belirlendi ( 1.75 ve 2.93 gün; $p=0.024)$. Sadece total antioksidan durumu (TAS) belirteci, grup I'de anlamlı olarak yüksek çıkmış ( $p=0.017)$ fakat bu durum komplikasyon oranları ile korele bulunmamıştır.

TARTIŞMA: Akut kolesistitli hastalarda, semptomların başlangııından itibaren 72 saatten fazla zaman geçmesine rağmen, ilk başvuruda kolesistektomi güvenli bulunmuştur. Operasyon öncesi serum oksidatif stres belirteçleri ile komplikasyon oranları arasında korelasyon kurulamamıştır. Anahtar sözcükler: 72 saat; akut kolesistit; ilk başvuru; oksidatif stres.

Ulus Travma Acil Cerrahi Derg 2019;25(5):440-446 doi: 10.14744/tjtes.2019.17807 